\title{
Solar Ready Buildings Planning Guide
}

\section{Technical Report} NREL/TP-7A2-46078

December 2009

L. Lisell, T. Tetreault, and A. Watson

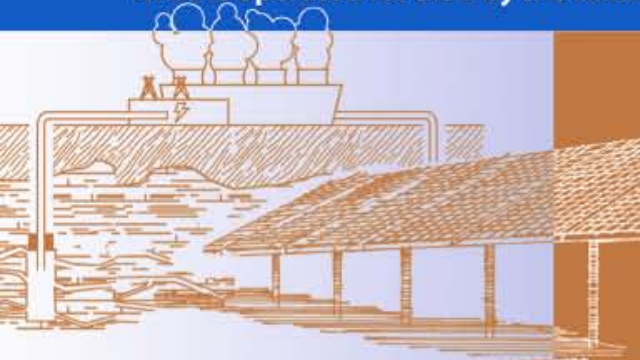




\section{Solar Ready Buildings Planning Guide}

\section{Technical Report}

NREL/TP-7A2-46078

December 2009

\section{Lisell, T. Tetreault, and A. Watson}

Prepared under Task No. PVC9.92DA

National Renewable Energy Laboratory

1617 Cole Boulevard, Golden, Colorado 80401-3393

303-275-3000 • www.nrel.gov

NREL is a national laboratory of the U.S. Department of Energy

Office of Energy Efficiency and Renewable Energy

Operated by the Alliance for Sustainable Energy, LLC

Contract No. DE-AC36-08-GO28308






\section{NOTICE}

This report was prepared as an account of work sponsored by an agency of the United States government. Neither the United States government nor any agency thereof, nor any of their employees, makes any warranty, express or implied, or assumes any legal liability or responsibility for the accuracy, completeness, or usefulness of any information, apparatus, product, or process disclosed, or represents that its use would not infringe privately owned rights. Reference herein to any specific commercial product, process, or service by trade name, trademark, manufacturer, or otherwise does not necessarily constitute or imply its endorsement, recommendation, or favoring by the United States government or any agency thereof. The views and opinions of authors expressed herein do not necessarily state or reflect those of the United States government or any agency thereof.

Available electronically at http://www.osti.gov/bridge

Available for a processing fee to U.S. Department of Energy and its contractors, in paper, from:

U.S. Department of Energy

Office of Scientific and Technical Information

P.O. Box 62

Oak Ridge, TN 37831-0062

phone: 865.576 .8401

fax: 865.576 .5728

email: mailto:reports@adonis.osti.gov

Available for sale to the public, in paper, from:

U.S. Department of Commerce

National Technical Information Service

5285 Port Royal Road

Springfield, VA 22161

phone: 800.553.6847

fax: 703.605.6900

email: orders@ntis.fedworld.gov

online ordering: http://www.ntis.gov/ordering.htm 


\section{Introduction}

This document identifies the important aspects of building design and construction to enable installation of solar photovoltaic and heating systems at some time after the building is constructed. This document addresses photovoltaic (PV), solar hot water (ST), and solar ventilation preheat (SVP) systems.

Often, the high initial cost of PV, ST, and SVP systems prevents them from being included in new construction. However, with better incentives, technological improvements, and rising conventional power prices, energy from solar sources will become more cost competitive. New construction that is solar ready will be in a position to take advantage of an environment more favorable to renewable energy. Without the forethought to make buildings solar ready, solar installation may not be technically possible or the added costs of making infrastructure changes may make solar applications economically prohibitive.

Planning for the eventual installation of a solar system when designing a building can significantly improve the economics of the investment. Installation efficiency can be maximized and costs minimized by understanding these systems' requirements and accounting for them during the design and construction of the building.

System performance is another significant contributing factor in the economics of PV, ST, and SVP systems. Similar to installation efficiency, system performance can be maximized by planning ahead during the design of the building.

The following guidelines indentify important system requirements for PV, ST, and SVP systems. Attention to these guidelines in the development of building codes, building design, or any building- or community-related regulations could significantly improve the performance and minimize the cost of solar systems.

\section{About this guide}

This document should be used as a guide to influence the design of new solar ready buildings. It outlines the scope of consideration that will minimize solar installation costs and maximize solar production potential when solar technologies are applied.

The guide is divided into two sections. A checklist provides quick reference and outlines the areas that need to be considered. The checklist references a second, descriptive section that provides detail and background information to the user.

This document was designed to be concise and hence accessible to users. When implementing the strategies outlined here, other resources must be consulted. The National Electric Code and local jurisdictions have specific requirements that apply to solar and must be considered. Local solar installers will be valuable resources at this early stage.

This guide was written with the focus on new construction. While many of the considerations are similar for retrofit or renovated buildings, there are other considerations to be made for retrofit projects that are not outlined here. 


\section{Solar Ready Checklist}

This guide is laid out in checklist form, with further information on each checklist item in the document below. The checklist will serve as a table of contents for the document as well as a quick reference tool for use when building plans are being developed. 


\section{General Solar Guidelines}

Avoid shading from trees, buildings, etc. (especially during peak sunlight hours). (More InfoAvoid Shading)

Check the zoning laws for the proposed site to ensure that future, neighboring construction will not cast shade on the array. (More Info - Zoning Laws)

Determine where a future solar array might be placed. (More Info - Solar Collector Placement)

If the roof is sloped, the south-facing section will optimize the system performance; keep the southfacing section obstruction-free if possible. (More Info - Site Orientation)

Minimize rooftop equipment to maximize available open area for solar collector placement. (More $\underline{\text { Info-Roof Obstructions) }}$

The type of roof installed can greatly affect the cost of installing solar later. (More Info- Roof Types)

The roof must be capable of carrying the load of the solar equipment. (PV - between 3 and $6 \mathrm{lb} / \mathrm{ft}^{2}$ ) (ST - between 2 and $5.5 \mathrm{lb} / \mathrm{ft}^{2}$ ) (More Info - Roof Load)

The wind loads on rooftop solar equipment must be analyzed in order to ensure that the roof structure is sufficient. See the American Society of Civil Engineers (ASCE) international building code 7-05 for the method of how to calculate these loads. (More Info - Wind Load)

Record Roof Specifications on Drawings. (More Info - Record Roof Specs)

Add additional safety equipment for solar equipment access and installation. (More Info - Safety Equipment) 
Decide where the solar panels will be mounted, and consider the different mounting strategies available. If the panels will be mounted on the roof with penetrating hardware, consider installing the mounting hardware at the time the roof is installed and use flashings for every penetration. (More $\underline{\text { Info - Panel Mounting) }}$

If the collectors will be placed on the roof, check if the roof installation carries a warranty.

Determine if the roof warranty contract has terms involving solar installation. (More Info - Roof Warranty)

Make sure all equipment is in compliance with the current version of the National Electrical Code. (More Info - Verify System Compliance)

\section{Additional Guidelines for Solar Thermal (ST) Systems}

Determine the hot water load and water temperature requirement to size all of the system components. Residential hot water usage can be calculated using the "Building America Research Benchmark Definition" by R. Hendron. (More Info - Sizing the System (ST))

Identify location for controllers, heat storage system, shutoff valves, and other equipment. (More $\underline{\text { Info - Equipment Space (ST)) }}$

Plan for all the necessary plumbing and provide pathways for water lines to link the solar collector, the heat storage system, and the rest of the building's hot water system. Also, be sure that the water distribution system and mixing valves are laid out to maximize the ST system performance. (More $\underline{\text { Info - Plumbing (ST)) }}$ 


\begin{tabular}{|c|c|}
\hline \multicolumn{2}{|l|}{ Additional Guidelines for Solar Ventilation Preheat (SVP) Systems } \\
\hline $\begin{array}{l}\text { Minimize the number of penetrations (windows, doors, etc.) through the south-facing wall. The } \\
\text { transpired collector can be installed around penetrations but excessive irregularities in the geometry } \\
\text { can limit the system performance. (More Info - Southern Wall Exposure (SVP)) }\end{array}$ & $\square$ \\
\hline $\begin{array}{l}\text { Provide direct access from transpired collector location on south wall to the outside air (OA) intake } \\
\text { duct of the air handling unit. (More Info - Duct Work Connection Access (SVP)) }\end{array}$ & $\square$ \\
\hline $\begin{array}{l}\text { Install a knockout and bypass damper in the first stage of the air handling unit to accommodate } \\
\text { ductwork from the transpired collector. (More Info - Duct Work Connection Access (SVP)) }\end{array}$ & $\square$ \\
\hline $\begin{array}{l}\text { Air handling unit fan should be sized to accommodate additional pressure drop from the transpired } \\
\text { collector. (More Info - Additional HVAC Equipment (SVP)) }\end{array}$ & $\square$ \\
\hline $\begin{array}{l}\text { Design control system to accommodate additional control points to control dampers. (More Info - } \\
\text { Additional HVAC Equipment (SVP)) }\end{array}$ & $\square$ \\
\hline $\begin{array}{l}\text { Design sufficient space between point sources of emissions (parking lots, delivery zones, etc.) and the } \\
\text { transpired collector. (More Info - Southern Wall Exposure (SVP)) }\end{array}$ & $\square$ \\
\hline $\begin{array}{l}\text { Design south wall to fire code standards to accommodate the installation of the transpired } \\
\text { collector. (More Info - Southern Wall Exposure (SVP)) }\end{array}$ & $\square$ \\
\hline
\end{tabular}




\section{Additional Guidelines for Photovoltaic (PV) Systems}

Identify electrical panel location for convenient PV system inter-connections, and keep space available in the electrical panel for a PV circuit breaker. (More Info - Electrical Panel Location (PV))

Specify panel capacity sufficient to accommodate the total power coming into the building (proposed PV system size power generation plus size of breaker protecting main panel). NEC allows for the sum of these two sources of power to be $20 \%$ greater than the panel rating. Consult the local authority having jurisdiction. (More Info - Electrical Panel Location (PV))

Lay out the locations for the inverter and the balance of system (BOS) components. (More InfoWiring Schematic (PV))

Identify the inter-connection restrictions for the location of the building site that apply to grid-tied PV systems. Begin by reviewing interconnection standards at http://www.dsireusa.org/. (More InfoGrid Inter-connection (PV))

Run electrical conduit from the solar collector location to the electrical panel and other electrical components. (More Info - Wiring Schematic (PV))

Consider any special load needs (i.e., uninterrupted power supply) and consider whether storage is needed. (More Info - Consider Special Loads (PV))

PV panels are much more sensitive to shading than ST panels. Avoid shading as much as possible. Due to the individual modules of a PV panel being connected in series, even a narrow strip of shading (lightning rods, antennas, etc.) can limit the current of the entire array. (More Info - Avoid Shading)

Find out what the energy production of the proposed system will be using the PVWatts calculation tool, and adjust the system size as

needed: http://rredc.nrel.gov/solar/codes algs/PVWATTS/version1/. (More Info - Sizing the System $\underline{(\mathrm{PV}))}$ 


\section{Detailed Solar Ready Building Guidelines}

\section{General Solar Guidelines}

Requirements for buildings to be ready for any type of solar system are detailed below.

\section{Avoid shading}

Shading will have an adverse effect on all the solar technologies discussed here and should be avoided. Use a sun path calculator, such as the Solar Pathfinder ${ }^{\mathrm{TM}}$, to assess shading at a particular location by analyzing the sky view where the solar panel will be located. Since the solar application may not be installed for several years, landscaping and future construction should be planned so as to avoid adversely affecting the solar resource.

PV panel performance is exceptionally susceptible to shading. When shade falls on a PV panel, that portion of the panel is no longer able to collect the high-energy beam radiation from the sun. If that shading happens during the peak hours of operation (10 a.m. -2 p.m.), the production of the panel can be greatly reduced. A PV panel is made up of many individual cells that all produce a small amount of current and voltage. These individual cells are connected in series to produce a larger voltage.

Figure 1 shows how a typical panel is laid out. If enough of the individual cells are shaded, the voltage will drop below the lower voltage limit of the panel and the entire panel will quit producing electricity. 


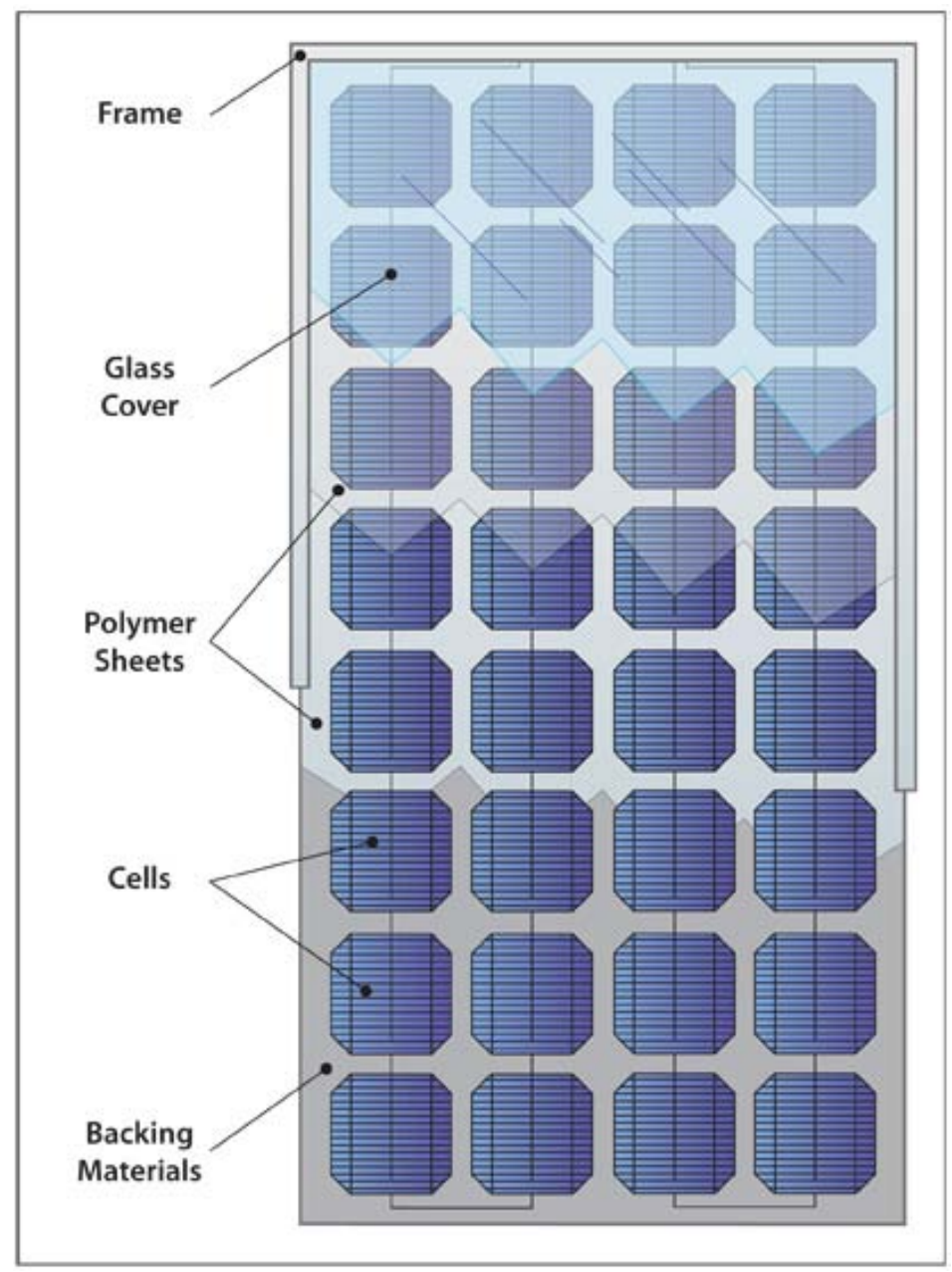

Figure 1. Typical PV panel construction

\section{(Return to Checklist)}

\section{Zoning Laws}

It is important to know and understand the local zoning laws and how they impact the installation of solar panels and the preservation of access to the solar resource. Properties located within historical districts or covered by a homeowners association may be subject to additional restrictions. There are some local governments that have instituted laws that protect the solar access of existing PV arrays; these laws are commonly referred to as solar easements. In most places, zoning laws are only applied to residential buildings. These and other laws can have a significant impact on the design and development of solar ready buildings. Speaking with a local official who understands local zoning laws and solar easements can save time by eliminating zone violations early on in the process.

\section{(Return to Checklist)}

\section{Solar Collector Placement}

In many cases, the roof is the best location for a PV or ST system. This is a convenient location because it is out of the way and usually un-shaded. In addition to roof locations, there are many 
other areas that also make good collector locations. Some of these include parking shade structures, large plots of land, and building integrated systems. When considering a solar system, all possible locations should be considered.

\section{(Return to Checklist)}

\section{Site Orientation}

Before ground is broken on a new construction project, consider whether the site layout can be improved to better incorporate a solar system. In most cases, the layout of a site can determine whether a solar system is feasible or not. See Figure 2 for two example scenarios where site layout greatly changes solar potential. In Site 1, a large amount of open space is available north of the buildings, but because of shading from the buildings, the area will be shaded for a large part of the year. In Site 2, the buildings and the parking lot were shifted to the north side of the site. This left the open space on the south side of the site, where shading from the buildings will not fall on the solar panels. By placing the buildings on a site with solar resource and shading in mind, the area available for solar panels can be greatly increased.

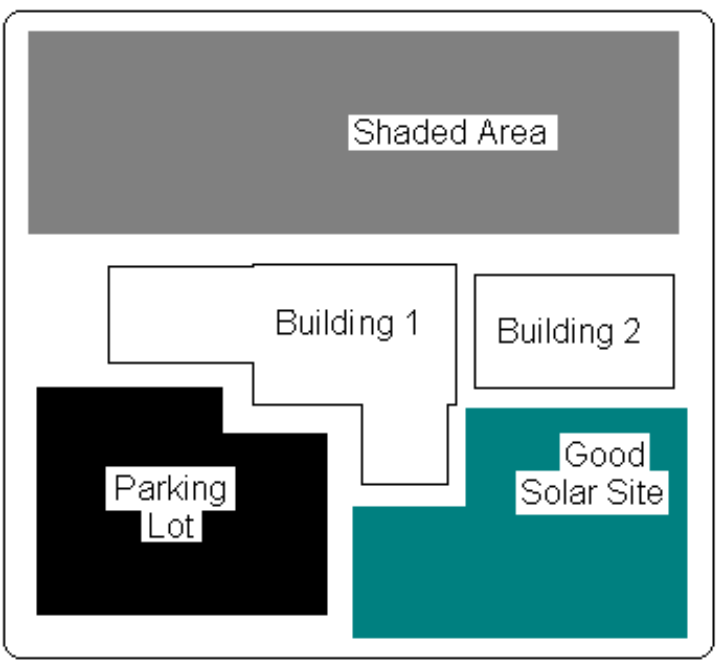

Site 1



Site 2

Figure 2. Usable solar area

If a building is designed with sloped roofs, it is best to orient the roof to maximize the roof area facing south (north-facing in the southern hemisphere). Placement on the south-facing section will ensure that the sunlight will strike the solar collector at a more optimal angle than it would if the collectors are placed on the east-, west-, or north-facing roof sections. The solar panels should be mounted on the south area of the roof and the mechanical equipment and vents should be located on the north area of the roof. Most solar collectors are mounted with a panel tilt angle, relative to horizontal, that is approximately equal to the site's latitude for maximum annual energy collection. Large systems with multiple rows have row spacing so each row gets full sun at 10 a.m. on the winter solstice.

(Return to Checklist) 


\section{Roof Obstructions}

It is important to maximize the size of unobstructed roof top area, and large contiguous areas are preferable. Minimize the rooftop equipment if possible. If mechanical equipment must be mounted on the roof it is best to designate a confined area for this equipment to allow more space for a PV or ST array. When selecting the confined equipment area, select a place that will not shade the roof area intended for the solar array. Rooftop equipment includes small obstructions such as rooftop vents, which should also be minimized.

\section{(Return to Checklist)}

\section{Roof Types}

The type of roof installed when a building is built can affect installation costs when solar is pursued on the building. The type, quality, and warranty of the roof can all play a part in determining the ease of a solar install. Solar PV panels often have a 25-year warranty. It is important to install a roof that will last at least as long. Also, the type of roof chosen can determine whether roof penetrations will have to be made, which may void the roof warranty.

\section{Flat Roofs:}

The best roof for a flat application is a fully adhered thermoplastic olefin or polyolefin (TPO) membrane roof. This roof is often an excellent choice for commercial applications, being both cost effective and more environmentally friendly than some other options. Other membrane roofs can also work well with solar such as ethylene propylene diene monomer (EPDM) or polyvinyl chloride (PVC). It is important to avoid river rock ballasted membrane roofs. Removing the ballast to install solar panels can be tedious and costly.

Sloped Roofs:

A standing seam roof is often the best option if solar is to be pursued at a later date. Solar panels can be attached to standing seam roofs without penetrating the roof. The standing seam roof itself must be attached to the structure well enough to withstand the additional loads of a solar array. Any shingled roof will require roof penetrations in order to attach solar racking. A tile roof poses challenges for installing a solar array and should be avoided if solar is planned for the structure.

(Return to Checklist) 


\section{Roof Load}

If the solar system is to be located on the roof of a building, roof structures must be designed to accommodate the additional dead loads (static load) and live loads (dynamic load) of the PV and/or ST system. Figure 3 illustrates the difference between live loads and dead loads. In the figure, the red arrows refer to the dead loads, and the blue arrows refer to the live loads. For a PV system, the solar panels and racking will add approximately 3 pounds for each square foot of collector area. If ballasted mounting is used, this number can be significantly higher ranging from 4-6 pounds per square foot of collector area. For a ST system, the solar panels will add different amounts of weight depending on the system type. For information on the selection of a ST system type visit the Solar Rating and Certification Corporation (SRCC) website at www.solar-rating.org. The following are examples from SRCC:

- Unglazed Solar Pool Heater - approx. $2.5 \mathrm{lb} / \mathrm{ft}^{2}$ of collector area ${ }^{1}$

- Glazed Flat Plate Collector - approx. $5.5 \mathrm{lb} / \mathrm{ft}^{2}$ of collector area ${ }^{1}$

- Evacuated Tube Collector - approx. $5.5 \mathrm{lb} / \mathrm{ft}^{2}$ of collector area. ${ }^{1}$

Some ST systems have storage capacity coupled with the collectors. For an integrated collector, the system weight is highly dependent on size of the storage tank. If the collector can hold 80 gallons of water, the increase in weight is nearly 700 pounds. In order to design the roof to accommodate the added weight of an integrated collector - storage system, the system should be sized and the weight of the system calculated. A good resource that can be used to find information on the performance and exact weight of various ST collectors is: http://www.solarrating.org/ratings/OG100DIRECTORIES/OG100DIRFULL.pdf.

In addition to the increased static load, consideration should be given to extraneous conditions that could be compounded due to a solar array (i.e., drifting snow, slow water runoff). In some cases this additional load can be many times the static load of a typical solar panel array. As mentioned above, when designing a building, it is critically important to be aware of the additional static and dynamic loads that could be imposed on the roof structure. The American Society of Civil Engineers (ASCE) international building code's chapter 7 can be used to calculate potential snow loads. There is more on loading in the next section.

\section{(Return to Checklist)}

\footnotetext{
${ }^{1}$ www.solar-rating.org
} 


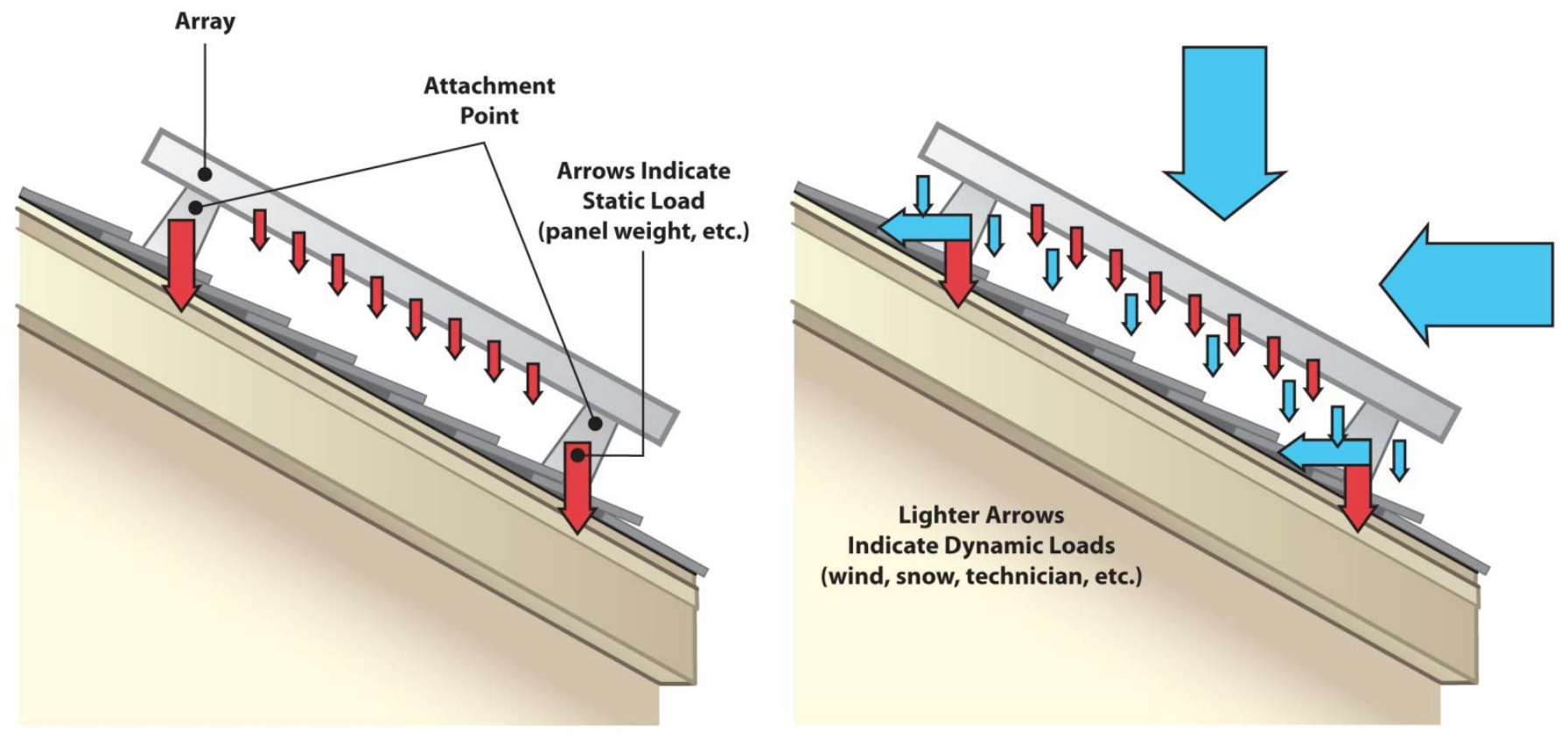

Figure 3. Live loads vs. dead loads

\section{(Return to Checklist)}

\section{Wind Load}

Roof structures should be designed to accommodate the dynamic loads resulting from wind incident upon the solar collectors. The wind load is dependent upon the building location, wind conditions, collector orientation, height exposure category, topography of the surroundings, and the roof zone placement of the solar collectors. If the collectors are flush mounted, the wind load will be comparable to the wind load occurring on the roof. If the collectors are rack mounted, the wind load can be increased significantly. Figure 4 shows the additional shear and normal forces from wind loading, but there can also be a significant bending moment that should be considered. This bending moment is normally not of significant concern. However, where the flat roof trusses run parallel with the rows of solar collectors and the mounting rack is designed and anchored in a specific way, a significant bending moment can be exerted on the roof trusses. When designing a building, it is important to be aware of these potential additional loads to ensure that the roof structure can comfortably handle all of the eventual loading conditions. Most solar panel mounting manufacturers include loading factor worksheets with their mounting hardware that can be used to calculate loads. Another resource to consult is the American Society of Civil Engineers (ASCE) international building code 7-05. Wind loading, snow loading, and other important factors are laid out in this document as well as methods to calculate these factors. Upon completing the calculations, a local solar installer or local building official should be contacted to verify the results and check the building code. 




Figure 4. Wind loading

\section{(Return to Checklist)}

\section{Record Roof Specifications}

If a roof has been designed to withstand additional loading from a solar array, it is crucial that this information is recorded so it is not lost to future solar developers. An ideal place to record this information is on the Drawing Package's Code Sheet.

\section{(Return to Checklist)}

\section{Safety Equipment}

Regardless of the location of the solar system, always consider appropriate safety measures. Maintenance, repairs, or inspections of the solar system require that a safety plan be developed. If the system is on a sloped roof, the building may need to be outfitted with a harness connection point. Additionally, fire code may require space around the edge of the roof where panels cannot be installed to allow safe access to all areas of the array. If the system is on the ground, a fence may need to be constructed around the system.

There are no national requirements for lightning protection of solar systems, but some organizations and state and local governments have internal requirements that should be considered during the design and construction of the building.

(Return to Checklist) 


\section{Panel Mounting}

There are several strategies available for mounting solar panels. If the proper wind and loading analysis has been done on a solar system, the appropriate mounts can be chosen and installed at the time of the building construction. There are different types of mounts available depending on whether the panels are mounted on the ground, a flat roof, a slanted roof, a wall, a pole, or elsewhere.

For flat surfaces, ballasted systems are available. Ballasted systems are racks that hold solar panels in place by adding a sufficient amount of weight to the frame of the rack. An example of a ballasted system can be seen in Figure 5. These systems save time and possible roof damage by avoiding penetrations. They also require significant additional weight on roofs and can add labor costs for the temporary removal of the system if the roof ever needs to be resurfaced. Slanted roofs can be direct mounted, rack mounted or standoff mounted. Ground mounted systems have a variety of mounting options available.

Before choosing one mounting option, explore all of the mounting options available for the specific site and roof configuration. Each system has pros and cons associated with it; the best mounting option often varies from site to site.

If you find that roof-penetrating mounts are best suited for the application, consider installing the roof penetrating mounts at the time of the roof installation. Once a building is finished, it can be costly to install anchoring mounts through the roof into the structural supports. When selecting penetrating mounts, verify that there is sufficient penetration into structural supports for the loading specifications (wind load, snow load, dead load, etc.).

It is also important to consider the impact of roof penetrations on the insulating value of the roof. Penetrating mounts can create a thermal bridge between the interior and exterior space and can cause humid interior air (especially in indoor pools) to condense and drip from cold roof penetrations. There are ways to mitigate this issue but it is important to be aware of the impacts of roof penetrations on the building system.

For every roof penetration, use flashing or flashed standoffs and appropriate sealing to ensure that the penetrations will not cause roof leaks. Consult a professional roofer for insight on the best way to seal specific roof types and verify that no roofing codes have been violated. Various penetrating mounts can be seen in Figure 6. 


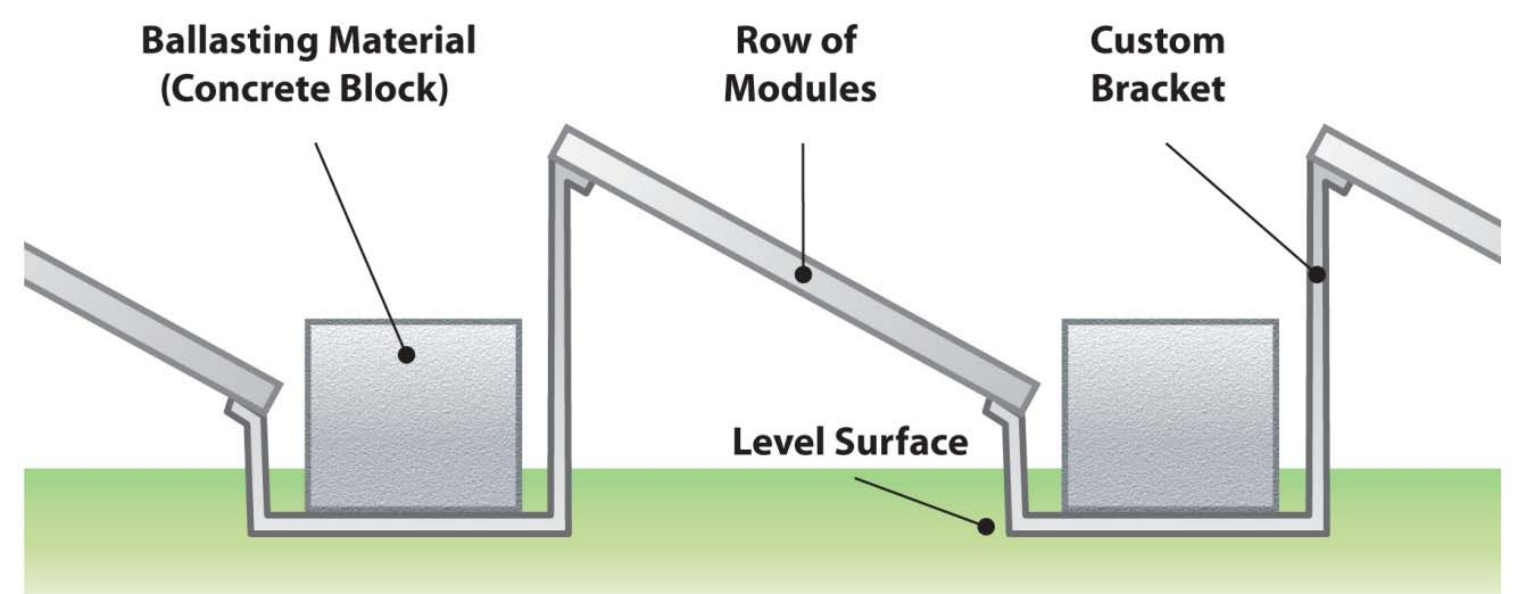

Figure 5. Ballasted mounting 

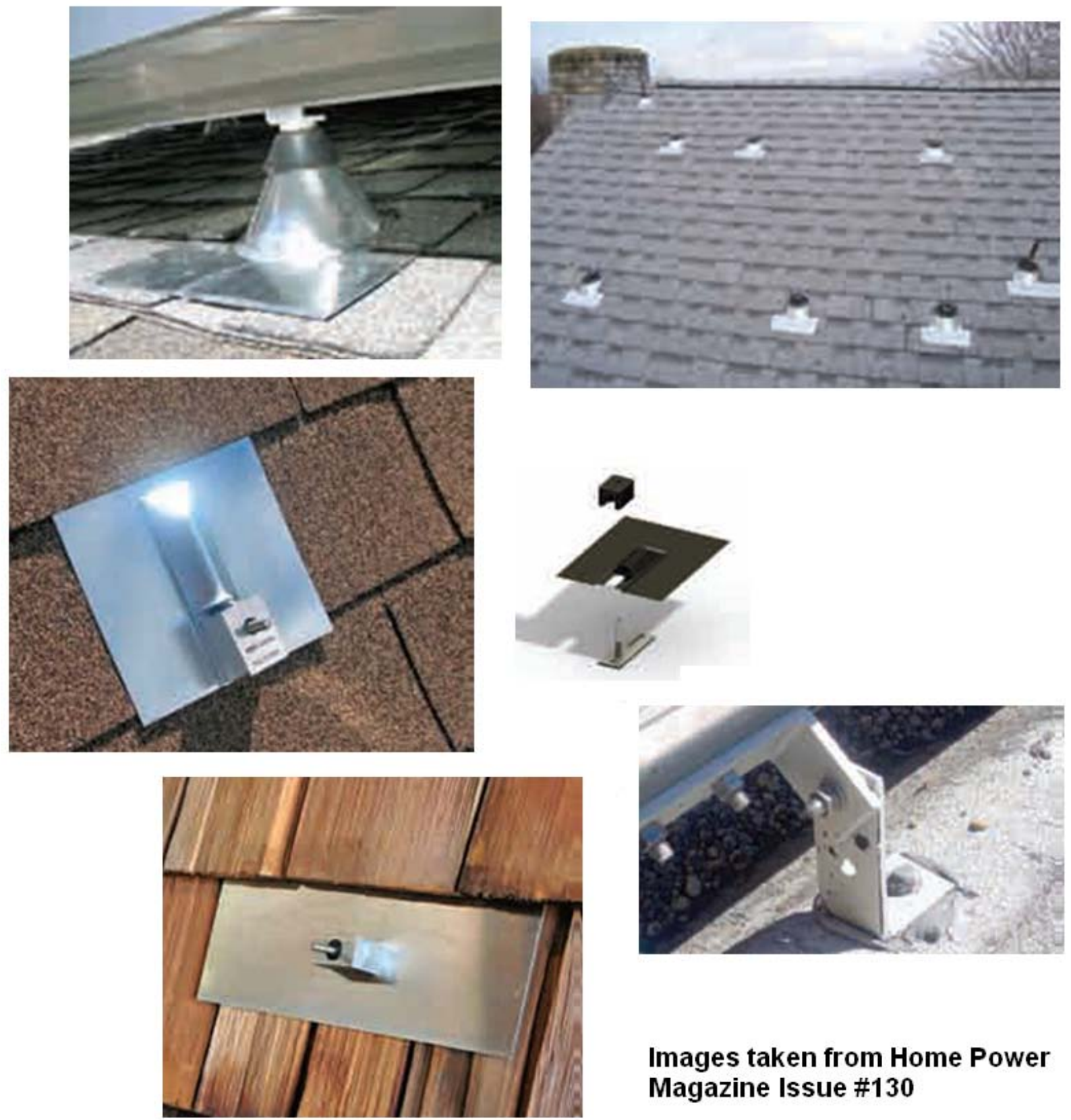

Figure 6. Penetrating mounts

Another thing to consider for roof-mounted systems is the albedo rating of the roof. If the roof is highly reflective, the benefit is two-fold. The roof will reflect more radiation on to the solar collectors, and the roof will stay cooler due to less solar radiation being absorbed. If the temperature of the roof is lower, the PV panels will be cooler and will operate at higher efficiencies.

\section{(Return to Checklist)}




\section{Roof Warranty}

Included in most roof warranty contracts are certain terms and conditions that must be followed in order for the warranty to be valid. In some cases, a certain style of roof mount must be used in order to comply with a roof warranty contract. Whether it means using a ballasted mount, or installing a certain style of flashing at each penetration, it is important to address roof warranty questions during the design and development of the project.

\section{(Return to Checklist)}

\section{Verify System Compliance with the National Electric Code}

When the electrical schematic is laid out for the solar system, verify that all wiring and grounding requirements follow the latest version of the National Electric Code (NEC). The NEC must be followed for both PV and ST systems, in addition to the state electric code. NEC Section 690, "Solar Photovoltaic Systems," was laid out specifically for PV installations and outlines the necessary requirements for installing the electrical equipment for a PV system to code.

\section{(Return to Checklist)}

\section{Solar Thermal (ST) Systems}

Additional requirements for buildings to be ready for solar thermal systems are detailed below.

\section{Sizing the System (ST)}

The size of an ST system should be found by estimating the building hot water usage, water temperature requirements, and hot water usage patterns. The "Building America Research Benchmark Definition" by R. Hendron is a good source of information for determining hot water usage of residential buildings. The document in PDF form can be found at http://www.nrel.gov/docs/fy08osti/42662.pdf. The information regarding hot water loads is located on page 11. The size of the system is useful for many structural calculations and also for mounting requirements. In order to correctly prepare for an ST system, the size of the system must be known. A general rule of thumb for cost effective ST applications is for a system to collect one-half to three-fourths of the annual thermal demands of a building. This solar fraction is dependent on the load profile and storage capacity of the system. A proper solar fraction helps prevent stagnation during the summer months in closed loop systems.

\section{(Return to Checklist (ST))}

\section{Equipment Space (ST)}

An ST system requires space for hot water storage, plumbing, mixing valves, controllers, and other required equipment. The ST system should be selected and laid out in order to provide the dimensions and space requirements necessary for the system. Depending on the size of the system, the hot water storage can be a significant point load and should be addressed in the design of the flooring. A general rule of thumb is 1-2 gallons of storage is required for every square foot of collector. Included in this space is the clearance required by building and plumbing code. Access to electricity to power the ST system equipment must also be considered. There are a wide variety of ST system styles, and each one requires different plumbing and equipment. Some of the systems will require a large equipment space, and others will require very little. Listed below are five system schematics showing the main components. The mixing 
valve is an important component that protects against the hot water supply getting too hot and should be incorporated in every ST system. If the ST system required for a building is large, consider developing a plan for installing the various system components to ensure that there are no problems fitting the equipment into the building through openings (doorways, windows, etc.). Also, to make the eventual installation of the ST system easier, it is recommended to include strategically placed "T joints" and shut-off valves in the plumbing of the hot water system. See Figure 7 below for an illustration of a typical plumbing schematic.



Figure 7. Plumbing schematic for eventual installation of ST system

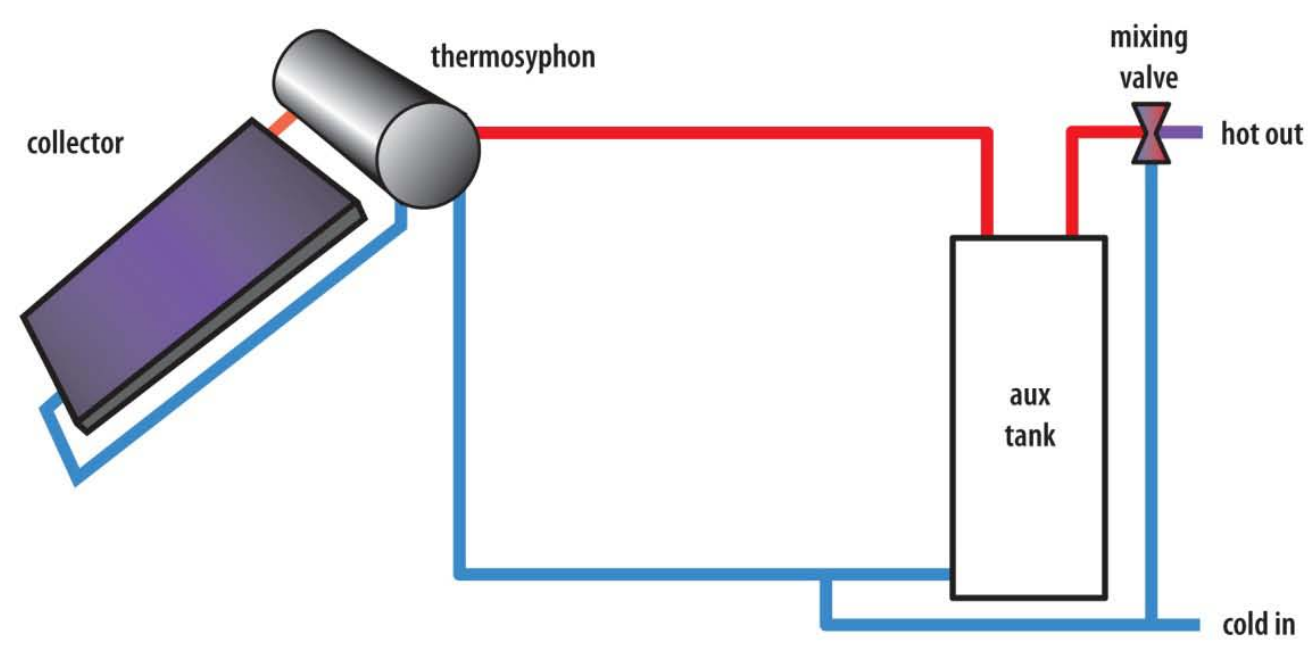

Figure 8. Thermosyphon system

Figure 8 is an example of a passive direct thermosyphon system. Water moves through this collector by convection only. The collector and the storage tank are mounted together, with the storage tank mounted just above the collector. 


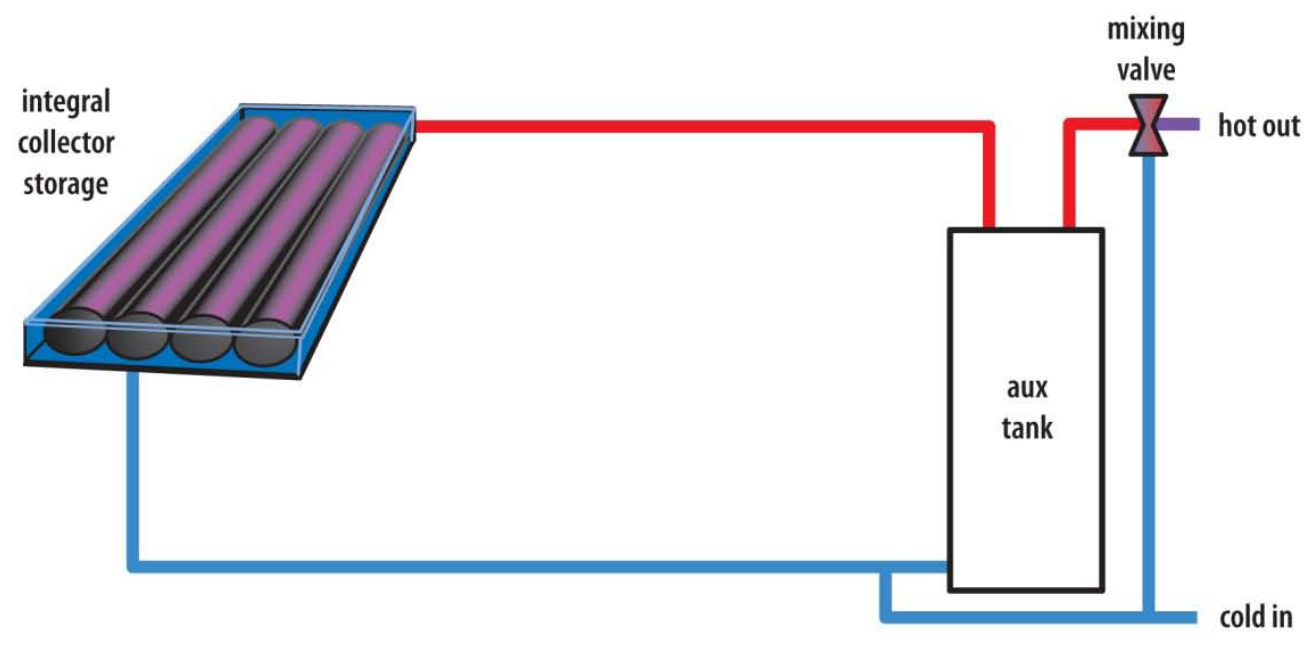

Figure 9. ICS system

Figure 9 is a passive direct integral collector storage (ICS) system. Water moves through this collector by convection only, and the collector holds a large volume of water, eliminating the need for a storage tank. This system is self-contained and needs only to be plumbed into the building water system. 


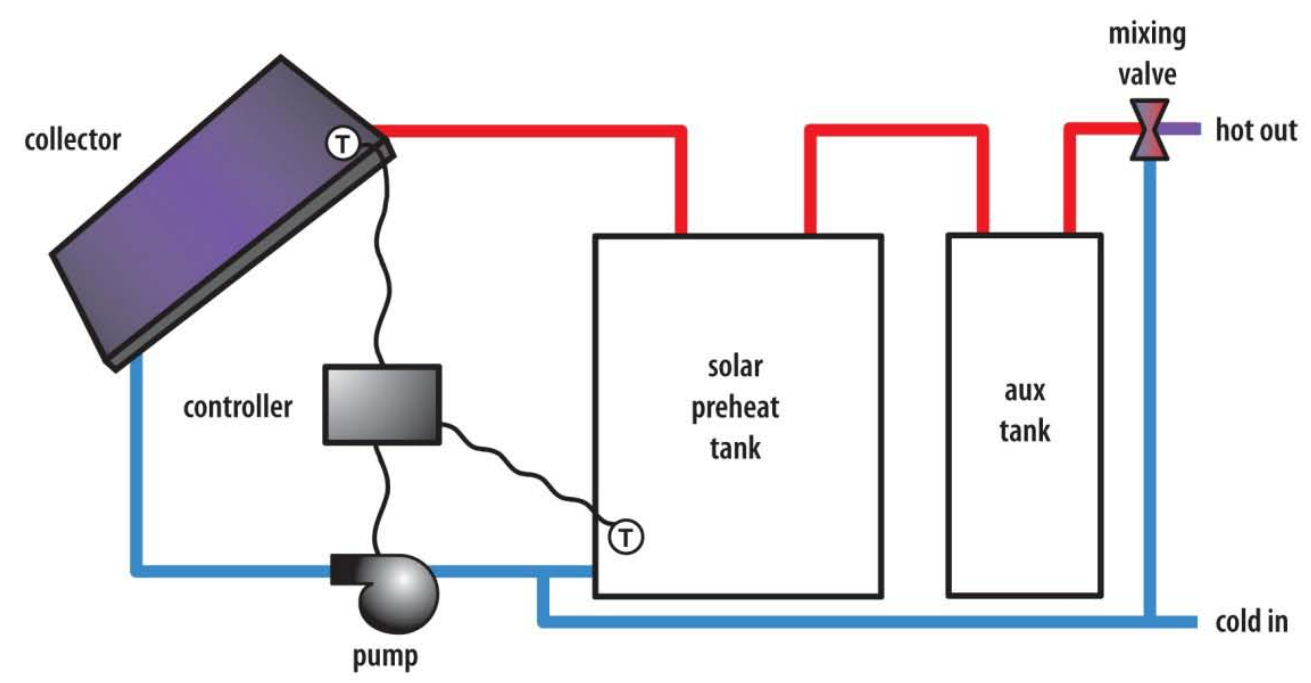

Figure 10. Direct system

Figure 10 is an active direct system. Water is pumped around this system when the controller detects that the collector is hotter than the preheat tank. This system requires space for a preheat tank, the controller, the pump, and the additional plumbing.

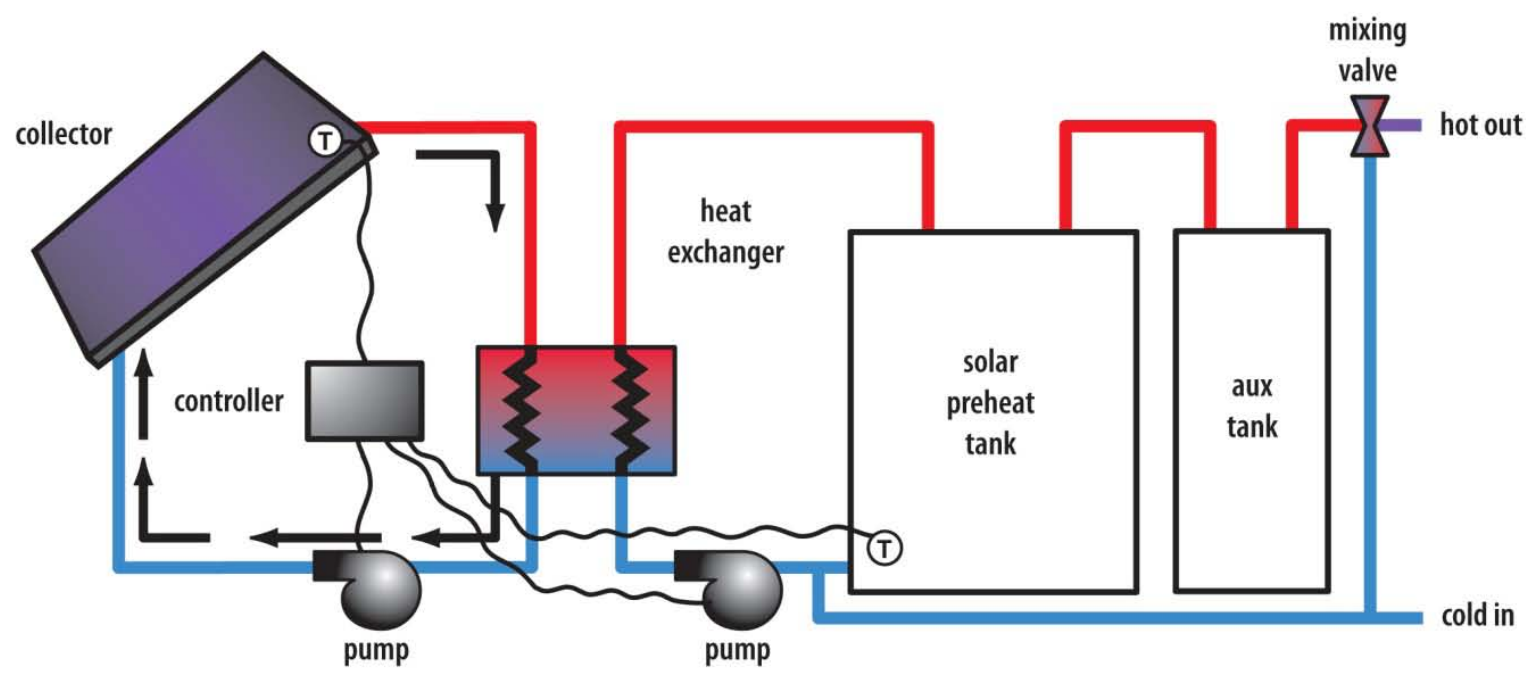

Figure 11. Indirect system

Figure 11 is an active indirect system. The heating fluid and the water are pumped through the heat exchanger when the temperature of the collector is greater than the solar preheat tank. This system requires equipment space for the preheat tank, the pumps, the controller, the heat exchanger, and the additional plumbing. 


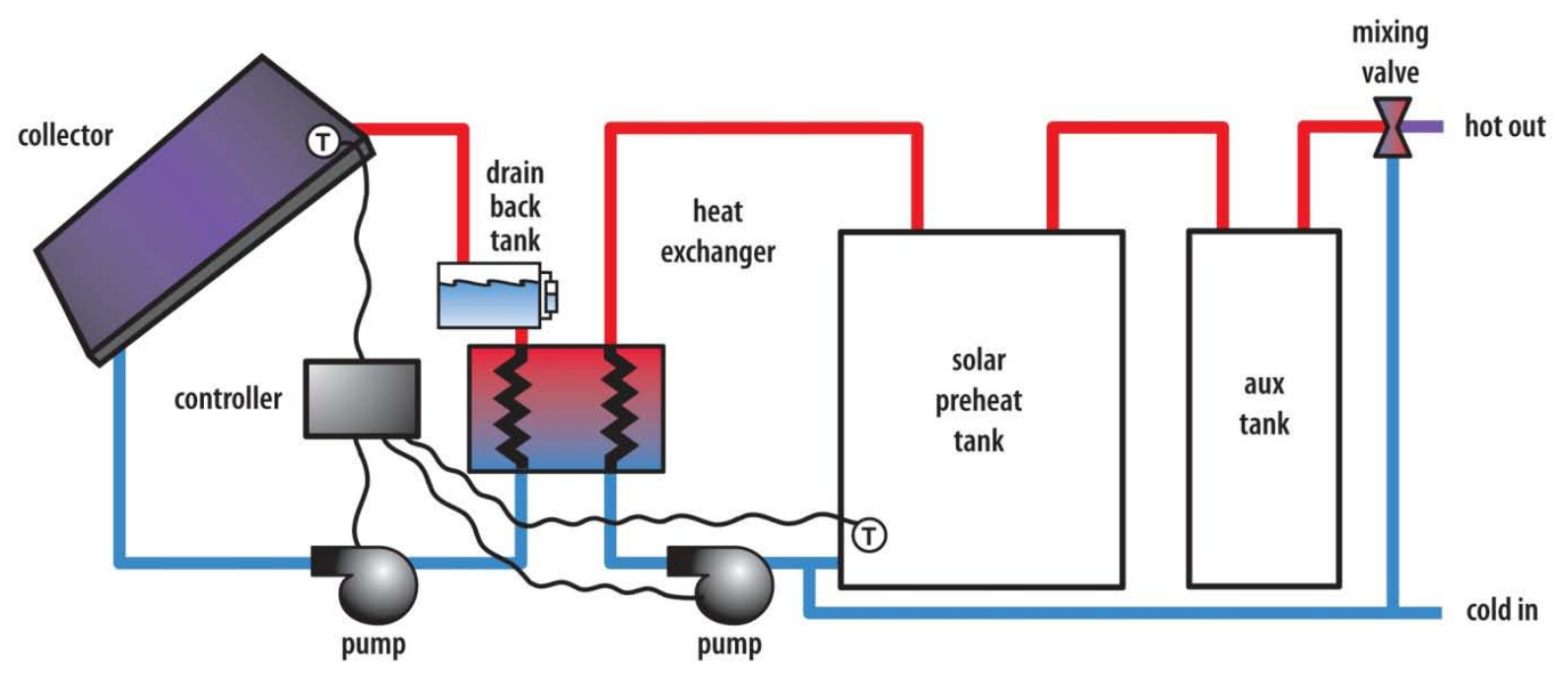

Figure 12. Drainback system

Figure 12 is an active indirect system as well. The heating fluid drains out of the collector when the pump is not pumping. This system requires equipment space for the preheat tank, the pumps, the controller, the heat exchanger, the drainback tank, and all the additional plumbing.

\section{(Return to Checklist (ST))}

\section{Plumbing (ST)}

The plumbing schematic for an ST system should be laid out at the time of building design. To enable ease of installation, plumbing from the roof to the equipment room should be installed when the building is first constructed. Any plumbing required for the system that goes through walls, floors, or other permanent structures should have the pathways planned out. If possible, there should be plumbing chases so that the piping can be installed quickly. Any plumbing that is installed should comply with all plumbing codes and plastic piping should not be used for ST applications. It is also recommended to use high temperature insulation on the ST system piping. The easily accessible plumbing can be done at the time of the system installation. Figure 13 shows some of the plumbing that must be installed along with an ST system. 


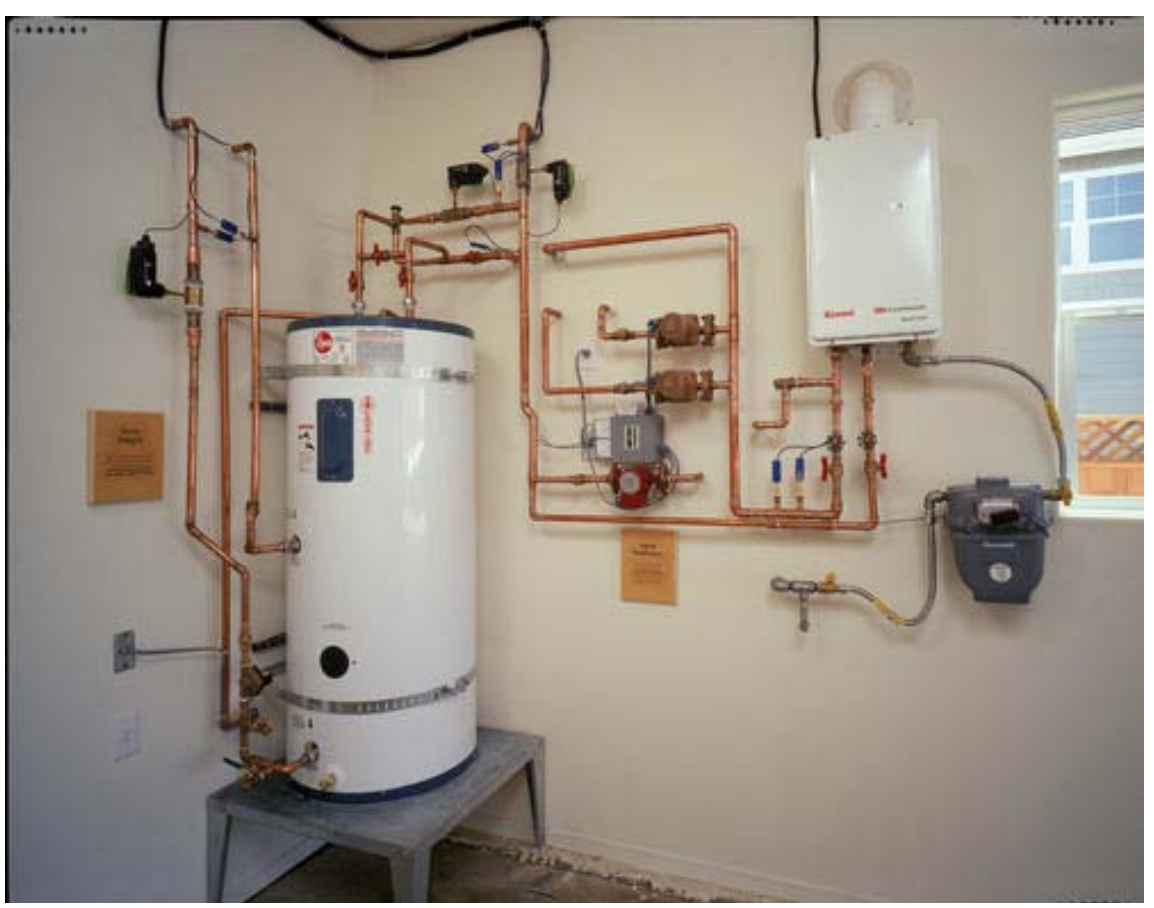

Figure 13. ST system plumbing

(Return to Checklist (ST))

\section{Solar Ventilation Preheat (SVP) Systems}

PV and ST systems are applicable to most residential and commercial buildings, whereas SVP systems are only applicable to buildings with $100 \%$ outside air or otherwise high ventilation requirements. Additionally, the building should have a relatively long heating season, as solar ventilation preheating works best in moderate to cold and sunny climates. Examples of potential candidate buildings include: industrial buildings, warehouses (especially those that house materials requiring continuous ventilation), laboratory facilities, gymnasiums, and aircraft hangars. Additional requirements necessary for buildings to be ready for a Solar Ventilation Preheat system are detailed below. 


\section{Solar Ventilation Preheat System Overview}

The solar ventilation preheat system works by heating outside air with a south-facing solar collector - a dark-colored wall made of sheet metal and perforated with tiny holes. Outdoor air is drawn through the holes and heated as it absorbs the wall's warmth. The warm air rises in the space between the solar wall and the building wall and is moved into the air-duct system, usually by means of a fan, to heat the building. Any additional heating needed at night or on a cloudy day is supplied by the building's conventional heating system. During the summer months, intake air bypasses the solar collector, preventing the system from supplying preheated ventilation air into the building. Figure 14 shows a diagram of a solar ventilation preheat system.


Figure 14. Solar ventilation preheat technology diagram

\section{(Return to Checklist (SVP))}

\section{Southern Wall Exposure (SVP)}

Minimize the number of penetrations (windows, doors, vents, etc.) through the south-facing wall where the system could potentially be placed. Some penetrations can be worked around if necessary, but excessive irregularities in the geometry can limit the system performance. The system needs sunlight to strike the collector directly for optimal performance, so walls that are curved or have surfaces that are not due south will limit the effectiveness of the system. The mounting area on the wall must also be fire resistant. When sun is striking the collector and there is no heating load, the collector can get extremely hot. In order to eliminate the risk of fire, the wall must be designed to fire code standards. Keeping in mind that the collector is pre-heating the air entering the building, specify that there is sufficient space between the collector and emission sources. Emission sources to consider are exhaust vents, loading docks, parking lots, on site generators, etc.

\section{(Return to Checklist (SVP))}




\section{Duct Work Connection Access (SVP)}

To allow for the streamline tie-in of the SVP collector to the HVAC system, provide direct access from the potential collector location on the south wall of the building to the outside air (OA) intake of the air-handling unit. There should be a knockout in the OA duct to help facilitate the quick installation of the SVP system. The knockout will reduce the extra costs that could be accrued from installing extra ductwork, and also will ensure that the air does not cool significantly before reaching the heating system. In addition, there should be a bypass damper to allow the SVP collector to be bypassed while the building cooling system operates.

\section{(Return to Checklist (SVP))}

\section{Additional HVAC Equipment (SVP)}

The resistance of air through the SVP collector is larger than the resistance of air through an outside air duct, thus increasing the pressure drop from the outside to the air-handling unit. This increased pressure drop requires a larger fan to move the air. When specifying the size of fan for the air-handling unit, be sure that the fan is large enough to accommodate the increased pressure drop. In addition, specify that the HVAC control system has a sufficient number of control points to operate the dampers required for the system.

\section{(Return to Checklist (SVP))}

\section{Photovoltaic (PV) Systems}

Additional requirements necessary for a building to be ready for a PV solar system are detailed below.

\section{Electrical Panel Location (PV)}

Because the PV system needs to be connected to the electrical system of the building, the electrical panel should be in a convenient location to connect to the PV array. The electrical panel must have sufficiently large amperage rating to accommodate the PV energy as well as grid energy. By Section 690 of the NEC, the sum of the ratings of over current protection devices in all circuits supplying power to an electrical panel must not exceed $120 \%$ of the busbar rating. When the electrical panel for the building is selected, verify that the total energy coming into the building (proposed PV system size energy generation plus grid energy) does not exceed $120 \%$ of the panel rating. There must also be space available in the electrical panel for a PV circuit breaker. Near the electrical panel there should also be a convenient location for the inverter and balance of system (BOS) components, with a sufficient amount of clearance in front of the components to comply with NEC. Some of the electrical components can be located outside if necessary, but exposure to heat and the elements will reduce the performance of the components over time in some cases.

\section{(Return to Checklist (PV))}

\section{Grid Inter-connection (PV)}

The grid inter-connection rules are different in every state, and sometimes even vary by city. Location-specific laws should be researched. The connection requirements vary depending on what type of grid the building is connected to and what the serving utility is. The serving utility representative should be contacted to determine what rules apply to the site. If the serving utility 
does not allow grid-interconnection, the possibility of implementing a solar array should not be eliminated. Each year more utilities are offering grid connection for solar arrays, and it is likely that it will be offered by all utilities in the near future. The rules and regulations associated with the grid inter-connection can be very specific, so it is important that the rules are fully understood. This process can be very time consuming, so it is beneficial to start the process well before the system is installed. A good place to get information on grid inter-connection and the various metering rules is: http://www.dsireusa.org/. Figure 15 shows two metering configurations that are widely used. These illustrate the inter-connection configuration known as "net metering". Net Metering is an electricity policy that allows a site with a PV system to send excess electricity to the grid and receive compensation. The compensation scheme is dependent on the servicing utility.

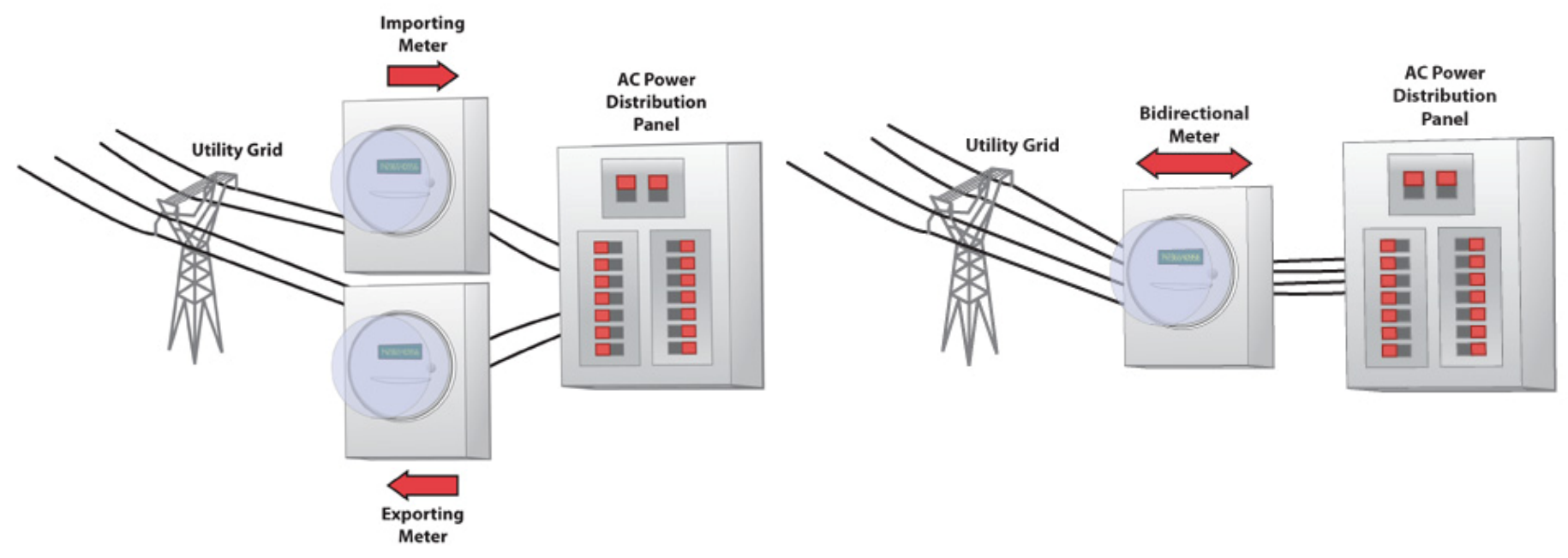

Figure 15. Dual and bi-directional metering configurations

\section{(Return to Checklist (PV))}

\section{Wiring Schematic (PV)}

The PV system will require conduit to go from the PV array to various electrical components. Figure 16 shows a PV system with an array and three of the many possible BOS components that must be connected to the array. Making sure there is adequate space for the BOS near the electrical panel is an easy step that can be taken during the building design phase and that will streamline installation at a later time.

An important consideration when designing a solar ready building is the conduit layout. Metallic conduit must run from the PV combiner box on the roof to the BOS space near the electrical panel. Ideally this conduit run is kept short to minimize voltage drop, and is planned for ahead of time for ease of installation. Running conduit through floors, ceilings, and walls during the initial construction will be much easier than doing it after the building is complete. Using an approximation of the eventual wiring schematic, conduit going through permanent structures should be installed. See the NEC for details on conduit and wiring requirements and verify that everything installed gets inspected for compliance with the latest NEC and the state electric and building codes. 
A monitoring system is a common component in PV installations. Monitoring allows tracking of solar system performance over the life of the system and makes it easy to identify systems that are performing below expectations and may be in need of maintenance. Monitoring systems require an Internet connection in the room that contains the inverter. Internet access to this space should be considered in the building design phase.

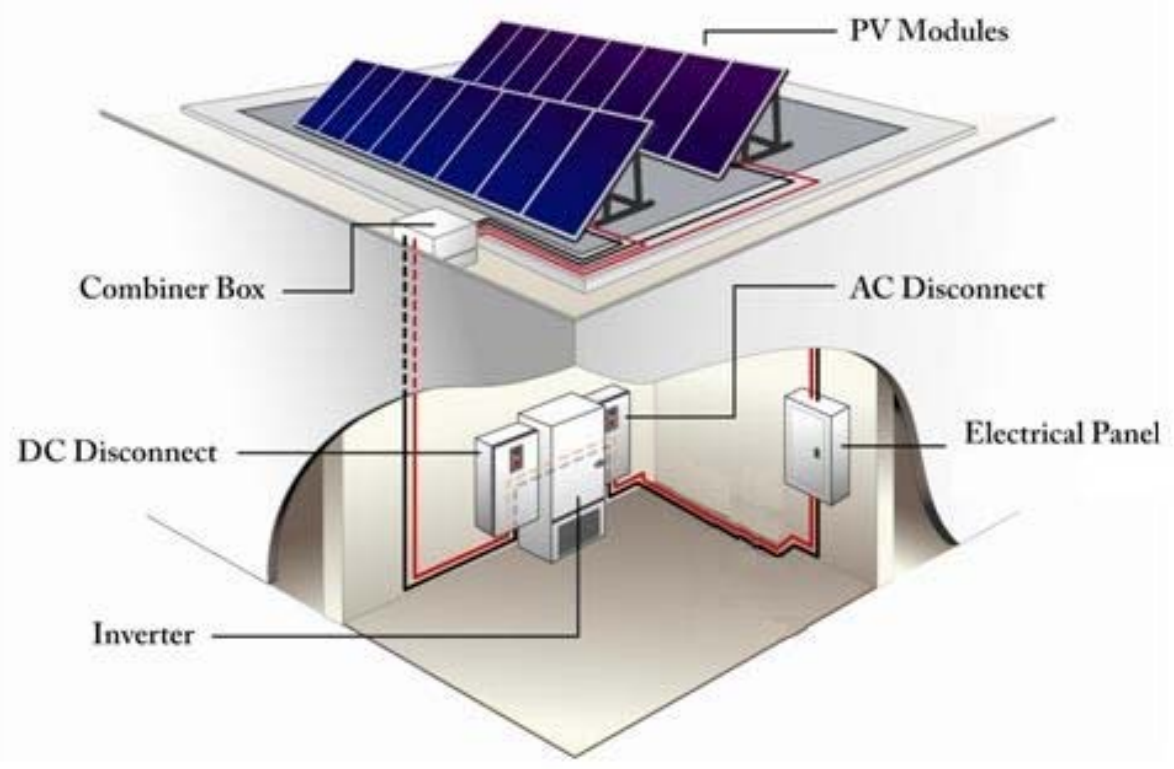

Figure 16. PV system components

\section{(Return to Checklist (PV))}

\section{Consider Special Loads (PV)}

If there are auxiliary systems that require uninterrupted power (i.e., security systems, fire alarms) consider available storage options. In the event of a power outage, the storage system would feed power to the system for a pre-determined amount of time. Figure 17 shows a possible configuration of components that will continue to deliver power to the critical load in the case of a grid power outage. Emergency call centers, fire and police departments, schools, and emergency shelters are often good candidates for battery-supported PV systems. 


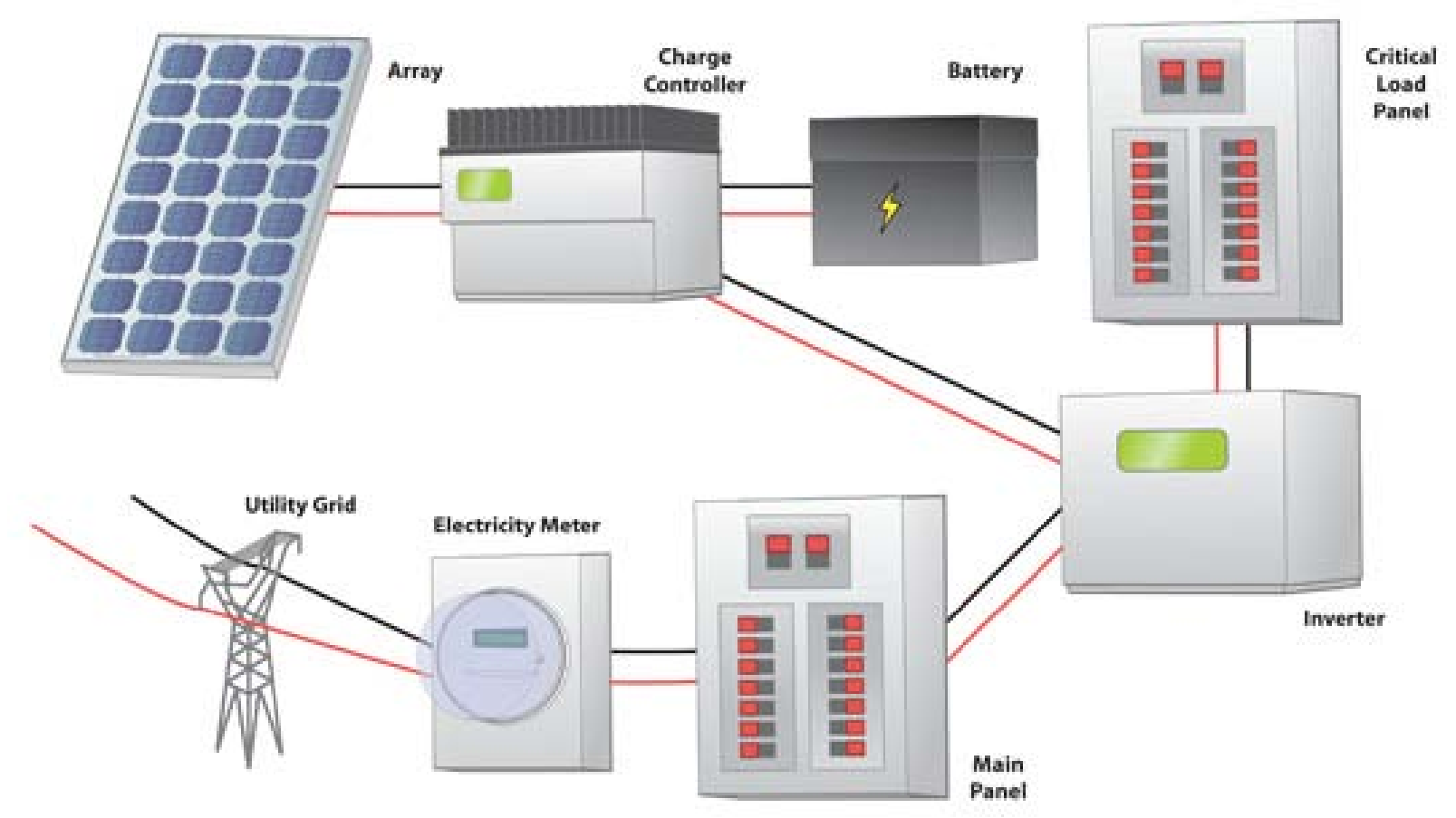

Figure 17. PV system with battery storage and grid connection

(Return to Checklist (PV))

\section{Sizing the System (PV)}

The size of the system will depend on the solar resource of the proposed location. The solar resource of the site should be researched to determine whether the site has sufficient resource to facilitate a PV system. Figure 18 shows a solar resource map of the United States. Site-specific hourly solar radiation can be found using the National Solar Radiation Database.

Yearly Data:

http://rredc.nrel.gov/solar/old data/nsrdb/1991-2005/hourly/list by state.html.

Typical Meteorological Year (TMY) Data:

http://rredc.nrel.gov/solar/old_data/nsrdb/1991-2005/tmy3/by_state_and_city.html.

When a building is being prepared for a solar installation, it is important to know the size of the proposed system so that all the correct preparations can be made. Typically, PV systems are designed only to provide a portion of the energy usage required by a site. In most places, it is not desirable to produce more energy than can be used on the site annually due to the low utility rate that is paid for electricity. For this reason systems are typically designed to meet $80 \%$ of the site energy usage to ensure that the system does not produce more energy than the site can consume, even during low energy consumption years. The National Renewable Energy Laboratory developed a Web-based calculation tool called PVWatts that can be used to size a PV system by finding the annual energy production of the system.(http://rredc.nrel.gov/solar/codes algs/PVWATTS/version1/). PVWatts uses the system size, orientation, location, and collector efficiency information to calculate the system output. If 
the annual energy production is not the desired amount for the specific site, the system size can be adjusted.

In order to determine what size PV system will fit in a designated area, the system type must be known. Each PV system will have a different area requirement, but typically similar technologies have similar footprint requirements per unit size. The following numbers can be used to find the approximate system size that can be placed in a given space.

- Crystalline PV System: 8-11watts/square foot

- Thin Film PV System: 5 watts/square foot

- HE Crystalline System: 17-18 watts/square foot



Figure 18. Solar resource map of the United States

(Return to Checklist (PV)) 


\section{Conclusion}

A few simple considerations when designing buildings will facilitate a smooth and cost effective transition to solar later in the building's life. In cases in which solar is not economically feasible during the initial construction phase, making the structure solar ready will help reduce the carbon footprint of the building over its lifetime and lower power costs when the solar system is installed. Furthermore, a solar ready building will position the building owner to take advantage of falling renewable energy prices in the future. Implementing policy that requires some or all new construction to be solar ready is a simple way community leaders can promote solar in their jurisdictions. With the aid of the Solar Ready Building Planning Guide, city planners, policymakers, and developers will be able to lay the foundation for Solar Cities. 


\section{REPORT DOCUMENTATION PAGE}

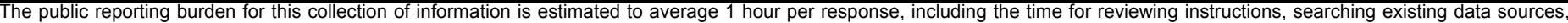

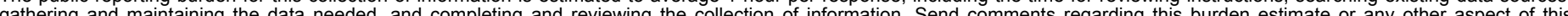
(0704-0188). Respondents

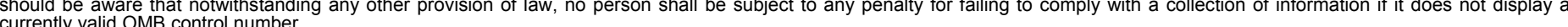

PLEASE DO NOT RETURN YOUR FORM TO THE ABOVE ORGANIZATION.

\begin{tabular}{l|l|l|l} 
1. REPORT DATE $(D D-M M-Y Y Y Y)$ & 2. REPORT TYPE & 3. DATES COVERED (FrOm - TO)
\end{tabular}

December 2009

Technical Report

4. TITLE AND SUBTITLE

Solar Ready Buildings Planning Guide

5a. CONTRACT NUMBER

DE-AC36-08-GO28308

5b. GRANT NUMBER

5c. PROGRAM ELEMENT NUMBER

6. AUTHOR(S)

L. Lisell, T. Tetreault, and A. Watson

5d. PROJECT NUMBER

NREL/TP-7A2-46078

5e. TASK NUMBER

PVC9.92DA

5f. WORK UNIT NUMBER

7. PERFORMING ORGANIZATION NAME(S) AND ADDRESS(ES)

National Renewable Energy Laboratory

1617 Cole Blvd.

REPORT NUMBER

Golden, CO 80401-3393

NREL/TP-7A2-46078

9. SPONSORING/MONITORING AGENCY NAME(S) AND ADDRESS(ES)

10. SPONSOR/MONITOR'S ACRONYM(S)

NREL

11. SPONSORING/MONITORING AGENCY REPORT NUMBER

12. DISTRIBUTION AVAILABILITY STATEMENT

National Technical Information Service

U.S. Department of Commerce

5285 Port Royal Road

Springfield, VA 22161

13. SUPPLEMENTARY NOTES

14. ABSTRACT (Maximum 200 Words)

This guide offers a checklist for building design and construction to enable installation of solar photovoltaic and

heating systems at some time after the building is constructed.

15. SUBJECT TERMS

PV; photovoltaic; solar ready; solar heating

\begin{tabular}{|c|c|c|}
\hline $\begin{array}{l}\text { a. REPORT } \\
\text { Unclassified }\end{array}$ & $\begin{array}{l}\text { b. ABSTRACT } \\
\text { Unclassified }\end{array}$ & $\begin{array}{l}\text { c. THIS PAGE } \\
\text { Unclassified }\end{array}$ \\
\hline
\end{tabular}

\begin{tabular}{l|l} 
17. $\begin{array}{l}\text { LIMITATION } \\
\text { OF ABSTRACT }\end{array}$ & $\begin{array}{l}\text { NUMBER } \\
\text { OF PAGES } \\
\text { UL }\end{array}$ \\
&
\end{tabular}

19a. NAME OF RESPONSIBLE PERSON

19b. TELEPHONE NUMBER (Include area code) 